CLINICAL STUDY

\title{
Molecular defects of the CYP21 gene in Spanish girls with isolated precocious pubarche
}

\author{
N Potau, S Riqué, I Eduardo, V Marcos ${ }^{1}$ and L Ibañez ${ }^{2}$ \\ Hormonal Laboratory, Hospital Materno-Infantil Vall d'Hebron, Autonomous University of Barcelona, ${ }^{1}$ Endocrinology Unit, \\ Corsorci Hospitalari de Terrassa and ${ }^{2}$ Endocrinology Unit, University of Barcelona, Hospital San Joan de Deu, Esplugas, Barcelona, Spain
}

(Correspondence should be addressed to N Potau, Hormonal Laboratory, Hospital Materno-Infantil Vall d'Hebron, Passeig Vall d'Hebron 119-129, 08035 Barcelona, Spain; Email:npotau@cs.vhebron.es)

\begin{abstract}
Objective: To determine the frequency of mutant alleles in the CYP21 gene in Spanish girls presenting with precocious pubarche (PP) and to assess the relationships between genotype and endocrinemetabolic variables.

Design: Fifty-three unrelated girls with a history of PP (14 prepubertal, 8 pubertal and 31 postmenarcheal) and 35 controls were studied.

Methods: Genomic DNA was extracted from peripheral blood leukocytes. After selection against the pseudogen, an allele-specific PCR was used to identify 14 known mutations in the CYP21 gene. The mutations studied were Pro30Leu, splice intron 2, Ilel72Asn, Cluster $\mathrm{E}_{6}$, Glyl92Ser, Ins T, GT-CT, Gln318-stop, Arg357Trp, Trp406-stop, Pro453Ser, Arg483Pro, Arg483 frameshift and Val281Leu. A standard 2-h oral glucose tolerance test was performed in all PP girls. Ovarian 17-hydroxyprogesterone (17-OHP) responses to gonadotrophin-releasing hormone-agonist stimulation was assessed in postmenarcheal PP girls.

Results: Thirteen PP girls and eight control girls were heterozygous for one of the mutations studied. The frequency of the carrier status was $25 \%$ and $23 \%$ in the PP and control groups respectively. Severe mutations were found in 33\% of the carrier girls. Serum 17-OHP responses to ACTH stimulation were similar in carriers and non-carriers (351 \pm 65 vs $334 \pm 22 \mathrm{ng} / \mathrm{dl}$ ). The presence of ovarian hyperandrogenism and/or hyperinsulinism was also not related to the carrier status.

Conclusion: The incidence of molecular defects in the CYP21 gene in the present study was comparable in the PP and control groups. We found no relationship between the presence of carrier status and endocrine-metabolic abnormalities. Prospective studies of larger cohorts of PP girls are needed to ascertain the long-term clinical relevance of CYP21 heterozygosity.
\end{abstract}

European Journal of Endocrinology 147 485-488

\section{Introduction}

Precocious pubarche $(\mathrm{PP})$ is defined as the appearance of pubic hair before the age of 8 years in girls and 9 years in boys (1). Most cases of PP are due to an early and isolated maturation of the zona reticularis of the adrenal gland (precocious adrenarche). Defective steroidogenesis indicative of non-classical adrenal hyperplasia $(\mathrm{NCAH})$ due to 21-hydroxylase deficiency is present in $7 \%$ of Spanish children with PP $(2,3)$; however, the incidence of this enzymatic defect in other populations has been reported to be higher $(1,4-6)$.

PP in girls is often preceded by a low weight at birth (7) and is associated with a constellation of postnatal endocrine-metabolic abnormalities including hyperinsulinaemia and dyslipidaemia of prepubertal onset, and functional ovarian hyperandrogenism $(\mathrm{FOH})$ and ovulatory dysfunction at adolescence (8-11). Genetic/ environmental factors acting in a complex multifactorial manner have been suggested to underlie this sequence $(12-14)$.

Previous studies in other populations have shown a high incidence of heterozygosity for CYP21 gene mutations in girls with PP and/or FOH (15-17). The aim of the present study was to determine the frequency of mutant alleles in the CYP21 gene in Spanish girls presenting with PP and to assess the relationships between genotype and endocrine-metabolic variables.

\section{Study population and methods}

\section{Study population}

A total of 53 unrelated girls with a history of isolated PP (age range, 6-18 years) and 35 control girls (age 
range, 8-15 years) were studied. Controls were selected from short-normal children (heights in the 10-25 centile range) and children seen by other paediatric subspecialties in Barcelona Hospital. Fourteen PP girls were prepubertal, eight pubertal and thirty-one postmenarcheal (18).

In all patients, PP was attributed to pronounced adrenarche, as suggested by elevated androstenedione and/or dehydroepiandrosterone sulphate (DHEAS) levels at PP diagnosis $(1,19)$ and by exclusion of $\mathrm{NCAH}$ by means of an adrenocorticotrophin (ACTH) test $(20,21)$. None of the subjects presented evidence for thyroid dysfunction or hyperprolactinaemia, or had a family or personal history of diabetes mellitus. Fifteen $(48 \%)$ of the postmenarcheal PP girls had $\mathrm{FOH}$, defined as a combination of at least three of the following: amenorrhea or oligomenorrhea (duration of menstrual cycles $\geq 45$ days); hirsutism (Ferriman and Gallwey score $\geq 8$ ) (22); elevated serum androstenedione, total testosterone and/or free androgen index (testosterone $\times 100 /$ sex hormone-binding globulin (SHBG), an index of free testosterone (23)); 17-hydroxyprogesterone (17-OHP) hyper-response $(\geq 160 \mathrm{ng} / \mathrm{dl})$ to gonadotrophin-releasing hormone agonist (GnRHa; leuprolide acetate (500 $\mu \mathrm{g}$ s.c.); Procrin; Abbott, Madrid, Spain) (10).

The clinical characteristics of the study population are described in Table 1.

\section{Methods}

Genomic DNA was extracted from peripheral blood leukocytes. After selection against the pseudogen, an allele-specific PCR was used to identify 14 known mutations of the CYP21 gene, according to the protocol of Wedell \& Luthman $(24,25)$. The mutations studied were Pro30Leu, splice intron 2, Ilel72Asn, Cluster $\mathrm{E}_{6}$, Glyl92Ser, Ins T, GT-CT, Gln318-stop, Arg357Trp, Trp406-stop, Pro453Ser, Arg483Pro, Arg483 frameshift and Val281Leu.

After 3 days of a high carbohydrate diet ( $300 \mathrm{~g} /$ day) and an overnight fast, a standard 2-h oral glucose tolerance test (oGTT) was performed in all PP girls. Oral glucose $(1.75 \mathrm{~g} / \mathrm{kg}$ body weight; maximum $75 \mathrm{~g})$ was given at $0800 \mathrm{~h}$, and blood was sampled at 0 , 30,60 and $120 \mathrm{~min}$ for measurement of glucose and immunoreactive insulin, as described (26). For calculation of mean serum insulin (MSI) during the oGTT, the area under the insulin curve was calculated according to the trapezoidal rule. MSI levels $\geq 54 \mathrm{IU} / \mathrm{l}$ per min in prepubertal girls and $\geq 84 \mathrm{IU} / \mathrm{l}$ per min in pubertal and postmenarcheal girls were considered abnormal $(8,9)$. All girls had normal glucose tolerance, according to the Expert Committee on the Diagnosis and Classification of Diabetes Mellitus criteria (27).

Postmenarcheal girls were studied either in the follicular phase of the menstrual cycle (days 3-8) or after 2 months of amenorrhea.

\section{Hormone assays}

Serum glucose was measured by the glucose oxidase method. Immunoreactive insulin was assayed by IMX (Abbott Diagnostics, Santa Clara, CA, USA). The mean intra- and interassay coefficients of variation were $4.7 \%$ and $7.2 \%$ respectively. Serum 17-OHP, testosterone, SHBG and DHEAS levels were assayed as previously described $(3,6)$. Serum samples were stored at $-20^{\circ} \mathrm{C}$ until assay.

\section{Statistical analyses and ethics}

Anthropometric data and hormonal results are expressed as means \pm S.E.M. unless stated otherwise. Comparisons were made by two-sided $t$-test. $P$ values $<0.05$ were considered statistically significant. Conditional regression analysis was performed to analyse the relationships between genotype and the different endocrine-metabolic variables.

The study was approved by the Institutional Review Board of Barcelona Hospital. Informed consent was obtained from parents and/or girls, as well as assent from minors.

\section{Results}

Thirteen PP girls and eight control girls were heterozygous for one of the mutations studied (Table 2). The frequency of the carrier status was $25 \%$ and $23 \%$ in the PP and control groups respectively. Severe mutations such as Gln318stop and intron 2 (655 A or $C$ to $G$ ) which abolish or severely impair enzyme activity were found in heterozygous form in 33\% of the carrier girls; conversely, mild mutations (Val218Leu, Pro453Ser and Pro30Leu) accounted for

Table 1 Clinical characteristics of the study population. Values are means \pm S.E.M.

\begin{tabular}{lrcccc}
\hline Study population & $\boldsymbol{n}$ & Age (years) & Post-ACTH 17-OHP (ng/dl) & MSI SDS & Post-GnRHa 17-OHP (ng/dl) \\
\hline PP prepubertal & 14 & $8.4 \pm 0.3$ & $236.1 \pm 39.1$ & $1.5 \pm 0.4$ \\
PP pubertal & 8 & $9.9 \pm 0.2$ & $256.8 \pm 83.4$ & $0.9 \pm 0.8$ \\
PP postpubertal & 31 & $13.7 \pm 0.4$ & $333.6 \pm 29.2$ & $2.1 \pm 0.3$ \\
Controls & 35 & $13.5 \pm 1.2$ & - & - \\
\hline
\end{tabular}

MSI SDS, mean serum insulin S.D. score. 
Table 2 CYP21 gene mutations in PP and control girls.

\begin{tabular}{lcc}
\hline Mutation & PP $(n=53)$ & Control $(n=35)$ \\
\hline Val281Leu & 3 & 4 \\
GIn318-stop & 4 & 2 \\
Pro453Leu & 3 & 1 \\
Pro30Leu & 3 & 0 \\
Intron 2 & 0 & 1 \\
Total & $13(25 \%)$ & $8(23 \%)$ \\
\hline
\end{tabular}

$67 \%$ of the mutations detected in both groups. Serum 17-OHP responses to ACTH stimulation were similar in carriers and non-carriers (351 \pm 65 vs $334 \pm 22 \mathrm{ng} / \mathrm{dl}$ ) (Fig. 1). Three heterozygous girls and three non-carrier girls had 17-OHP values post ACTH between 500 and $1000 \mathrm{ng} / \mathrm{dl}$.

The presence of $\mathrm{FOH}$ and/or hyperinsulinaemia was also not related to the carrier status, as only four (27\%) of the 15 postmenarcheal girls with $\mathrm{FOH}$ and two $(8 \%)$ of the $24 \mathrm{PP}$ girls with abnormal MSI levels were found to have mutations in the CYP21 gene.

\section{Discussion}

NCAH due to 21-hydroxylase deficiency is probably the most frequent autosomal recessive genetic disorder in humans (4). The incidence of NCAH among children presenting with PP based solely on biochemical assessment has been reported to vary from $0 \%$ to $40 \%(2,3$, 5, 6, 28-32). Molecular studies, however, have shown that the frequency in non-Jewish Caucasian populations is less than $10 \%(4)$.

The incidence of molecular defects of the CYP21 gene in the present study was comparable in the PP and control populations ( $25 \%$ vs $23 \%$ respectively). In a small population of PP boys $(n=7)$, heterozygosity for this molecular defect was also $28 \%$ (authors, unpublished observations).

Previous reports have shown higher (15) or similar frequencies $(17,33,34)$ of heterozygosity in both PP

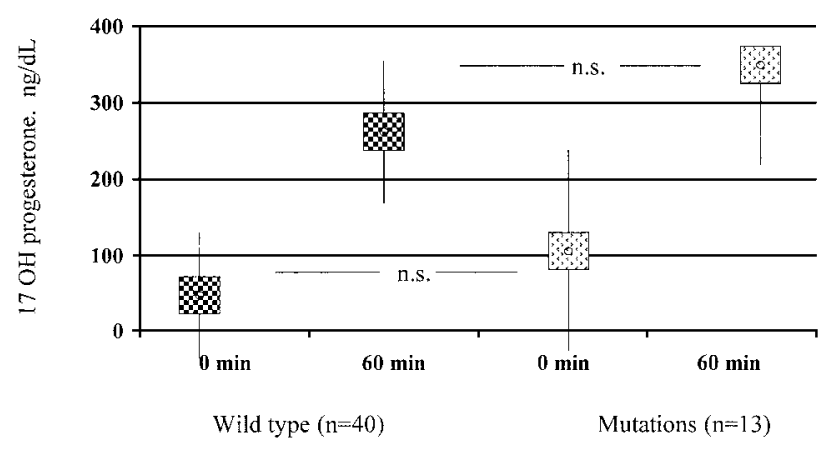

Figure 1 Baseline and post-ACTH 17-hydroxyprogesterone levels in PP girls with (right-hand pair of symbols) and without (left-hand pair of symbols) mutations. n.s., not significant. Values are means \pm S.E.M. children and hyperandrogenic women. However, some of these studies included patients with NCAH (15), were performed in unselected groups of hirsute women (34), or included different racial groups (17). In our series, the frequency of heterozygosity in the control group was found to be unexpectedly higher than previously reported in other Caucasian populations $(16,17,33,34)$. The observed carrier frequency might be accounted for by a series of founder effects, genetic drift, or a high frequency of de novo mutations (35).

We found no relationship between the presence of a carrier status and the subsequent development of $\mathrm{FOH}$ at adolescence. Indeed, the presence of CYP21 mutations was equally prevalent among PP patients who developed FOH and those who did not. Heterozygosity for 21-hydroxylase deficiency has been suggested to increase the risks of developing clinical signs of androgen excess $(16,33,34,36)$; however, additional studies in obligate heterozygotic carriers have failed to show evidence of these associations (37). This phenotypic heterogeneity may reflect the effects of other multiple susceptibility genes or allelic variants, genetically based variations in androgen biosynthesis or sensitivity to androgens, epigenetic influences, and/or the role of environmental factors $(17,35,38)$.

One-third of heterozygotes in both the PP and control populations were found to have severe CYP21 gene mutations that abolish or severely impair enzymatic activity. Although the frequency in this and other hyperandrogenic populations (27) has to be taken into account, the available data do not allow conclusions to be drawn with regard to the need for genetic counselling in this population at such an early age. In conclusion, the incidence of molecular defects in the CYP21 gene in the group of Spanish girls with PP was comparable with the control group. Prospective studies of larger cohorts of PP girls are needed to ascertain the long-term clinical relevance of CYP21 heterozygosity, before considering the need for genetic counselling in selected cases.

\section{References}

1 Ibáñez L, DiMartino-Nardi J, Potau N \& Saenger P. Premature adrenarche - normal variant or forerunner of adult disease? Endocrine Reviews $200021671-696$.

2 Ibañez L, Bonnin MR, Zampolli M, Prat N, Alia PJ \& Navarro MA. Usefulness of an ACTH test in the diagnosis of nonclassical 21-hydroxylase deficiency among children presenting with premature pubarche. Hormone Research 199544 51-56.

3 Machuca I, Ibáñez L, Bonnín MR, Rosel P, Arranz B \& Navarro MA. Routine detection of point mutations in non-classic steroid 21-hydroxylase deficiency. International Journal of Clinical and Laboratory Research 199727 257-260.

4 Speiser PW, Dupont B, Rubinstein P, Piazza A, Kastelan A \& New MI. High frequency of non-classical steroid 21-hydroxylase deficiency. American Journal of Human Genetics $1985 \mathbf{3 1}$ $650-667$. 
5 Siegel SF, Finegold DN, Urban MD, McVie R \& Lee PA. Premature pubarche: etiological heterogeneity. Journal of Clinical Endocrinology and Metabolism 199274 239-247.

6 del Baizo P, Borrelli P, Gambiano P, Danielli E \& Cappa M. Adrenal steroidogenic defects in children with precocious pubarche. Hormone Research 199237 180-184.

7 Ibáñez L, Potau N, Francois I \& de Zegher F. Precocious pubarche, hyperinsulinism and ovarian hyperandrogenism in girls: relation to reduced fetal growth. Journal of Clinical Endocrinology and Metabolism 199883 3558-3662.

8 Ibáñez L, Potau N, Zampolli M, Riqué S, Saenger P \& Carrascosa A. Hyperinsulinemia and decreased insulin-like growth factor binding protein-1 are common features in prepubertal and pubertal girls with a history of premature pubarche. Journal of Clinical Endocrinology and Metabolism 199782 2283-2288.

9 Ibáñez L, Potau N, Chacón P, Pascual C \& Carrascosa A. Hyperinsulinemia, dyslipemia and cardiovascular risk in girls with a history of premature pubarche. Diabetologia $1998 \mathbf{4 1}$ 1057-1063.

10 Ibáñez L, Potau N, Virdis R, Zampolli M, Terzi C, Gussinyé M et al. Postpubertal outcome in girls diagnosed of premature pubarche during childhood: increased frequency of functional ovarian hyperandrogenism. Journal of Clinical Endocrinology and Metabolism 199376 1599-1603.

11 Ibáñez L, de Zegher F \& Potau N. Anovulation after precocious pubarche: early markers and time course in adolescence. Journal of Clinical Endocrinology and Metabolism $1999842691-2695$.

12 Ibañez L, Castell C, Tresserras R \& Potau N. Increased prevalence of type 2 diabetes mellitus and impaired glucose tolerance in firstdegree relatives of girls with a history of precocious pubarche. Clinical Endocrinology 199951 395-401.

13 Ibáñez L, Ong KO, Potau N, Marcos MV, de Zegher F \& Dunger DB. Insulin gene VNTR genotype and the low birthweight, precocious pubarche and hyperinsulinism sequence. Journal of Clinical Endocrinology and Metabolism 200186 5788-5793.

14 Ibáñez L, Valls C, Potau N, Marcos MV \& de Zegher F. Polycystic ovary syndrome after precocious pubarche: ontogeny of the low-birthweight effect. Clinical Endocrinology 200155 667-672.

15 Dacou-Voutetakis C \& Dracopoulou M. High incidence of molecular defects of the CYP21 gene in patients with premature adrenarche. Journal of Clinical Endocrinology and Metabolism $1999841570-1574$.

16 Witchel SE, Lee PA, Sudahartman M \& Hoffman EP. Hyperandrogenism and manifesting heterozygotes for 21-hydroxylase deficiency. Biochemical and Molecular Medicine $199762151-158$.

17 Witchel SF, Smith R, Tomboc M \& Aston CE. Candidate gene analysis in premature pubarche and adolescent hyperandrogenism. Fertility and Sterility 200175 724-730.

18 Marshall WA \& Tanner JM. Variations in the pattern of pubertal changes in girls. Archives of Diseases in Childhood $1969 \mathbf{4 4}$ $291-303$.

19 Rosenfield RL. Normal and almost normal precocious variations in pubertal development. Premature pubarche and premature thelarche revisited. Hormone Research 199441 (Suppl 2) 7-13.

20 New MI, Lorenzen F, Lerner AJ, Kohn B, Oberfield SE \& Pollack MS. Genotyping steroid 21-hydroxylase deficiency: hormonal reference data. Journal of Clinical Endocrinology and Metabolism $1983563320-3325$.

21 Sakkal-Alkaddour H, Zhang L, Yang X, Chang YT, Kappy M, Slover RS et al. Studies of $3 \beta$-hydroxysteroid dehydrogenase genes in infants and children manifesting premature pubarche and increased adrenocorticotropin-stimulated $\Delta^{5}$-steroid levels. Journal of Clinical Endocrinology and Metabolism $1996 \mathbf{8 1}$ $3961-3965$.
22 Ferriman D \& Gallwey JD. Clinical assessment of body hair growth in women. Journal of Clinical Endocrinology and Metabolism 1961 21 1440-1447.

23 Ibáñez L, Potau N, Zampolli M, Prat N, Gussinyé M, Saenger P et al. Source localization of androgen excess in adolescent girls. Journal of Clinical Endocrinology and Metabolism 199479 1778-1784.

24 Wedell A \& Luthman H. Steroid 21-hydroxylase deficiency: two additional mutations in salt-wasting disease and rapid screening of disease-causing mutations. Human Molecular Genetics 19932 499-504.

25 Wedell A. Molecular genetics of congenital adrenal hyperplasia (21-hydroxylase deficiency): implications for diagnosis, prognosis and treatment. Acta Paediatrica 199887 159-164.

26 Potau N, Ibañez L, Riqué S \& Carrascosa A. Pubertal changes in insulin secretion and peripheral insulin sensitivity. Hormone Research 199748 219-226.

27 The Expert Committee on the Diagnosis and Classification of Diabetes Mellitus, Report of the Expert Committee on the Diagnosis and Classification of Diabetes Mellitus. Diabetes Care 199720 1183-1197.

28 Temeck JW, Pang S, Nelson C \& New MI. Genetic defects of steroidogenesis in premature pubarche. Journal of Clinical Endocrinology and Metabolism 198764 609-617.

29 Morris AH, Reiter EO, Geffner ME, Lippe BM, Itami RM \& Mayes DM. Absence of nonclassical congenital hyperplasia in patients with precocious adrenarche. Journal of Clinical Endocrinology and Metabolism $198969709-715$.

30 August GP, Hung W \& Mayes DM. Plasma androgens in premature pubarche: value of 17-hydroxyprogesterone in differentiation from congenital adrenal hyperplasia. Journal of Pediatrics 197587 246-249.

31 Oberfield SE, Mayes DM \& Levine LS. Adrenal steroidogenic function in a black and Hispanic population with precocious pubarche. Journal of Clinical Endocrinology and Metabolism 1990 $7076-82$.

32 Leite MV, Mendoncca BB, Arnhold IJ, Estefan V, Nunes C, Nicolau W et al. Identification of nonclassical 21-hydroxylase deficiency in girls with precocious adrenarche. Journal of Endocrinological Investigation $1991 \mathbf{1 4} 11-15$.

33 Ostlere LS, Rumsby G, Holowniat P, Jacobs HS, Rustin MHA \& Honour JW. Carrier status for steroid 21-hydroxylase deficiency is only one factor in the variable phenotype of acne. Clinical Endocrinology $1998 \mathbf{4 8}$ 209-215.

34 Escobar-Monrreale HF, San Millán JL, Smith RR, Sancho J \& Witchel SF. The presence of the 21-hydroxylase deficiency carrier status in hirsute women: phenotype-genotype correlations. Fertility and Sterility $1999 \mathbf{7 2}$ 629-638.

35 White PC \& Speiser PW. Congenital adrenal hyperplasia due to 21-hydroxylase deficiency. Endocrine Reviews $2000 \quad 21$ 245-291.

36 Blanché H, Vexiau P, Clauin S, Le Gall I, Fiet J, Mornet E et al. Exhaustive screening of the 21-hydroxylase gene in a population of hyperandrogenic women. Human Genetics $1997 \mathbf{1 0 1}$ 56-60.

37 Knochenhauer ES, Cortet-Rudelli C, Cunnigham RD, ConwayMayers BA, Dewailly D \& Azziz R. Carriers of 21-hydroxylase deficiency are not at increased risk for hyperandrogenism. Journal of Clinical Endocrinology and Metabolism 199782 479-485.

38 Strauss JF III \& Dunaif A. Molecular mysteries of polycystic ovary syndrome. Molecular Endocrinology 199913 66-73.

Received 10 August 2001

Accepted 30 May 2002 